million ( $£ 1,500$ million), and universities and research throughout the country are on short commons. Accounting Office contested on economic grounds the priority set by the Reagan Administration on the first US fast breeder planned at Clinch River, Tennessee, at an estimated cost of $\$ 3,500$ million.

Heinz Riesenhuber, Christian Democrat spokesman on energy, has emphasized the importance of both West German reactors
It is relevant that in July the US General

for the country's industrial future. It is reported that CDU/CSU would finance the reactors by reallocating research funds. The commission's report goes to the Bundestag this week, but voting may await resolution of the current Bonn crisis. The reactors' future would be safest with a $\mathrm{CDU} / \mathrm{CSU}$ coalition (their main candidate for minister of research and technology is Albert Probst - chairman of the intraparliamentary research committee).

Sarah Tooze

CERN

\section{Electrons collide environmentally}

The European Centre for Nuclear Research (CERN, near Geneva) is still battling with the politics of its next big project the large electron-positron collider, LEP. Although LEP was officially approved at the international CERN Council last December, local French opposition has again reared its head. But CERN is in such a hurry to get LEP built that it seems prepared to ignore opposition, and even, effectively, to 'gag' members of its own staff.

The problem is "environmental" approval. LEP must meet the regulations of France and Switzerland, through both of which it passes. Swiss law is already satisfied. But the French environmental hearings have only just started, and strenuous objections are already coming from the little village of Echevenex, tucked under the Jura Mountains six miles from the present CERN site.

Some 30 CERN staff live in the village, which is a well-known thorn in the CERN flesh. Last year the mayor, M. Honorat, managed to halt construction of a pilot tunnel under the Jura, and was finally overruled by the highest French legal body, the Conseil d'Etat. Since then both LEP and M. Honorat have changed their positions - LEP to avoid construction problems under the Jura, eliminating the need for the tunnel, and M. Honorat for reasons of his own. LEP appeared to be safe.

However, the new path of LEP, although out of the Jura, comes much closer to Echevenex - and brings with it one of the four primary experimental halls, which will appear on the surface like a 400-metre-long factory, only 250 metres from the edge of the village, which looks down on the site across a valley. "It's a beautiful spot" said one resident last week. "The hall would go where the children like to play, and where we pick nuts". The site would be an eyesore in what is essentially a rural retreat, say the villagers - and it would bring noise.

The objections may be dismissed as romantic - unless one lives there - but CERN director-general Professor Herwig Schopper wrote recently that "We should aim not merely at LEP being tolerated by the local inhabitants, but at making them proud supporters of CERN as a positive asset in their neighbourhood". Echevenex villagers see little sign of those ideals. At a meeting with CERN officials in the village on 2 July this year, the CERN reply to a question about noise was "you'll get used to it".

This apparently unhelpful attitude incensed even CERN employees in the village, and one of them, say the villagers, began to raise technical questions. For his pains, however, the employee was carpeted, and his attention drawn to a clause in the CERN employment contract which reads "Members of the personnel shall refrain from an act or activity which is incompatible with their functions or which would be materially or morally prejudicial to the organization". Clearly frightened for his future, he withdrew from the discussion. Since then, CERN has published a notice which indicates that employees are free to act in their interests, within the national law of their place of residence but that they must also take note of their conditions of employment; thus, if they criticize CERN they are in danger.

What happens next depends on how CERN chooses to react, and on the process of French law. According to CERN foreign relations director, M. Lévy-Mandl, CERN is likely to make "only small adjustments" to its plans. It would be technically possible to move buildings, he said, but this would slow the rate at which experiments could be moved in and out, compromise safety and increase costs. Representations to this effect would be made to the Commission of Inquiry, a body of six local personalities now taking local views on LEP according to French law. This commission will present its conclusions to the French government, which must then decide whether or not to give LEP the status of being "in the public interest"; construction could then go ahead.

It seems inconceivable, now, that approval will not be given - so the question facing the government, with its professed concern for regionalism, is simply how far to take into account the Echevenex. Will the Echevenex halls be just where CERN says they should be? Or where the villagers would like them?

Robert Walgate objections of the little village of
UK nuclear power

Decision time

The management style of the United Kingdom Atomic Energy Authority may be subtly changed from 1 October, with the accession of Sir Peter Hirsch, the Oxford metallurgist, as the authority's part-time chairman. Since 1967, the successive chairmen of the authority (Sir John Hill and Sir Walter Marshall) have been fulltimers from the nuclear industry.

Most immediately, the change will probably mean more responsibility for $\mathrm{Mr}$ A. M. Allen, deputy chairman of the authority for the past year and previously responsible for finance and administration. Mr Allen, who describes himself as a "lapsed historian", is now the authority's chief executive. Whether and to what extent Sir Peter Hirsch will think it politic to follow his predecessors in outspoken advocacy of a strong British nuclear programe remains to be seen.

In the public inquiry on the proposed pressurized water reactor for Sizewell (Suffolk), which is due to get under way early next year, the running is likely to be made by the Central Electricity Generating Board, the purchaser of the plant. The authority's chief concern is the programme of fast reactor development centred on the Prototype Fast Reactor at Dounreay, now costing close on half the authority's net budget ( $£ 201$ million in the year ending last March).

The Department of Energy has made encouraging noises in the House of Commons about the continuation of this programme, which among other things is an important source of employment in the north of Scotland. The authority's annual report, published this week, says that problems with leaks in the steam evaporators (through which molten sodium from the reactor core circulates) continued during the past year, reducing the power output of the reactor and thus the amount of spent fuel available for reprocessing through the experimental plant at Dounreay.

The next milestone for the British fast reactor programme will be the government's decision on the proposal to build a commercial demonstration reactor, the capital cost of which is now estimated at 20 per cent more than the Advanced Gas Cooled Reactor being built at Heysham. The government has been brooding about this decision for at least the past two years.

The possibility of partnership with the Commissariat a l'Energie Atomique on the Superphénix programme seems to have receded as the French programme itself has faltered. Nobody seems to know how to devise a framework for Anglo-American collaboration that would survive the confusion about the Clinch River fast breeder reactor.

In the end, much will depend on how much the Central Electricity Generating 